\title{
Controlling the Risks from Liquefied Natural Gas *
}

\author{
by Emilio Biamonte **
}

\section{Introduction}

In 1944, the Cleveland, USA accident occurred. A gas explosion and formation of a globe of fire caused huge losses described as follows : 136 deaths, neighbouring roads swept by burning gas, broken window panes, manhole covers blown over buildings, an antifire pump projected into the air. This was an LNG peak-shaving plant.

For several years after the accident, scepticism induced a certain slowdown of investment in this area. Nevertheless, in view of the new energy requirements and the environment, the interest in liquefied gas grew very quickly and developed faster in the 1960 s to reach the present level of operation. Since 1944, no major accident has been reported, and therefore no statistical approach to forecast accidents in this field is possible. On the other hand, due to the hazardous nature of the business, the industry has put great emphasis on accident prevention, but there is still little knowledge on gas behaviour in case of accident. An number of studies on different aspects related to accidents in this field have been promoted but are yet sufficient to assess with certitude the consequences of an accident. Furthermore, studies are often criticised by other parties. On the whole, the case of liquefied gas looks very much like that of nuclear power : low frequency/high impact accidents, certain unknown phenomena, violent reaction from the public and self-defence of industry which invests heavily in safety and appears to have the situation well in hand.

The purpose of this article is to outline the profile of this sector for those who are not familiar with it and to make the reader appreciate the interests at stake.

In fact, the LNG industry developed to satisfy our energy needs and, in the new energy world picture, it is expected to grow at an accelerated rate.

But let us first resume some basic notions.

* Reduced version of a report to "The Geneva Association". Basic data refer to those available in 1981.

** Battelle Research Centers, Geneva. 


\section{Background}

Natural gas is one of the world's major commercial fossil fuels. Table 1 gives a recent estimate of recoverable fossil fuels by type to be able to judge the importance of natural gas. The table also shows the world's consumption in 1978 of these major fossil fuels.

Table 1 : Fossil fuels reserves and consumption

\begin{tabular}{|l|c|c|}
\hline Fuel type & $\begin{array}{c}\text { Recoverable reserves } \\
\text { energy content } \\
\left(10^{6} \text { terajoules }\right)\end{array}$ & $\begin{array}{c}1978 \text { consumption } \\
\left(10^{6} \text { tonnes oil equivalent }\right)\end{array}$ \\
\hline Solid fuels & 15000 & 1811.3 \\
Crude oil & 3950 & 3075.9 \\
Natural gas & 1950 & 1240.5 \\
\hline
\end{tabular}

As can be seen, natural gas presently accounts for some $20 \%$ of the total energy supplies. Its importance is a result of its suitability both as a fuel and as a feedstock for petrochemicals production as well as its qualities as a clean fuel in an increasingly pollution-conscious world.

The conventional means of transporting natural gas - pipelines - have always required that the gas-producing and consuming areas be contiguous and thus natural gas as an energy fuel was denied to world areas without indigenous production. This to some extent is being overcome with ambitious deep-sea pipeline projects (North Africa/Italy, North Africa/Spain). However, the main driving force to develop remote natural gas reserves has undoubtedly been the development of a means by which natural gas can be moved in liquefied form.

Natural gas is therefore suitable for use both as a fuel and a feedstock. The major part of natural gas consumption is for industrial and domestic heating, as a result of its high heating value and pollution-free combustion. It is also used as feedstock to produce hydrogen, fertilizers and many other petrochemicals.

In liquefied form as LNG, natural gas is also suitable as a transport fuel for vehicles and aircraf, but to date there has been no wide application in this sense.

\section{The LNG system}

What is normally called "LNG system" includes :

- A liquefaction plant, normally located at the LNG export terminal and linked by pipeline to the gas-producing fields. After a pre-treatment to eliminate undesired components, gas is cooled at approximately $-161^{\circ} \mathrm{C}$ and liquefies. There are basic 
processes adopted for this operation and the most popular are the cascade cycle (successive cooling by propane, ethylene and methane in three separate heat exchangers) and the propane pre-cooled mixed refrigerant process (where propane cools both the natural gas feed to the liquefaction unit and the refrigerant, which is a mixture of gases). The process choice largely depends on the gas quality and plant size.

- A storage unit for liquefied gas before it is loaded onto the LNG tanker. There are five major storage systems of which the established ones are : the above-ground or below-ground double-walled metal tanks, the pre-stressed concrete above-ground tanks. However, base load operations at loading and market ports require large storage capacities and the storage facility is essentially a surge tank which smoothes out the non-uniform base load demand and fuel delivery operations.

- An LNG ocean tanker, highly sophisticated carrier, having to maintain the gas at a temperature of $-162{ }^{\circ} \mathrm{C}$, necessitating a special ballasting system because of the low-density cargo, largely propelled by the $0.2-0.3 \%$ per day boil-off gas feeding the steam turbines ${ }^{1}$.

The basic types of designs are divided by IMCO (Intergovernmental Maritime Consultative Organization) in four categories, two of which are applied : independent tanks (spherical, trapezoidal, vertical or horizontal cylinders, self-supporting, independent from the ship's hull) and membrane tanks (non-self-supporting, consisting of a thin layer supported through insulation by the adjacent hull structure). Capital cost is lower for the membrane system, but quality-control problems are not negligible, and much care is required during construction and inspection. Finally, the independent tank is often considered to offer more protection in case of collision.

- $A$ regaseification plant, designed to raise the gas temperature to close to ambient temperature, based on two basic systems : indirect heat exchange with river or sea water, or burning hydrocarbon fuel. This last one, called gas-fired, has several variants.

\section{Size of the operations and investments}

\section{Export terminals}

Existing liquefaction capacities vary from 100 MMSCFD $^{2}$ for those built in 1964-1965 to a maximum of 1000 MMSCFD for the most recently built unit in Algeria (1978). Projects under construction are sometimes small (under 100 MMSCFD for

1 Regulations impose that not more than $90 \%$ of the fuel needed be boil-off generated, the rest being fuel oil.

2 Millions of Standard Cubic Feet per Day. 
those in Nigeria) but the most often the capacity is around 500 up to the 850 MMSCFD for the Malaysian project. The same range of capacities applies for the probable and the possible other projects.

\section{LNG tankers}

The average vessel capacity has also steadily increased from the $25-30000 \mathrm{~m}^{3}$ of those built from 1966 to 1980 up to the order of $130000 \mathrm{~m}^{3}$ for those built around 1980 . In this case, one can notice a certain single-capacity stabilization. The delivery price in 1981 for a carrier of such capacity is approximately 150 million US \$.

\section{Import terminals}

Their operation capacities vary from 150 to 1000 MMSCFD of gas/day and their storage capacities range from 1000 to $20000 \mathrm{MMSCF}$ of gas (approx. equivalent to 50 to $900000 \mathrm{~m}^{3}$ of $\mathrm{LNG}$ ).

The total investment for an import terminal of capacity typical for the next projects (500-600 MMSCFD) is in the order of 200 million US $\$, 75 \%$ of which are direct costs.

\section{Peak-shaving facilities}

These are small capacity gas treatment, liquefaction and storage units with a highcapacity vaporizer to supply peak-shaving needs when the pipeline capacity cannot meet peak demand.

Storage capacities range from 150 to 4000 MMSCF of gas (approx. 7000 to $180000 \mathrm{~m}^{3}$ of $\mathrm{LNG}$ ).

\section{Satellite facilities}

There are small facilities similar to a peak-shaving plant but without a liquefaction plant. LNG is normally supplied by tank truck for base load or peak-shaving purposes remote from the main plant. The larger satellite plants (approx. $800 \mathrm{~m}^{3}$ in LNG storage volume) are erected in the field. Smaller units generally use shop build-up cryogenic tanks for storage.

\section{Present size and expected growth of the LNG industry}

The amount of internationally traded gas in 1979 is estimated at $6 \times 10^{12} \mathrm{ft}^{3}, 78 \%$ of which transferred by pipeline and $22 \%$ as LNG. By 1990 , the volume of traded gas should approximately double, and the share transferred as LNG should make approximately $40 \%$ of the total. This means that the amount of gas traded as LNG will be 
close to four times as much in 1990 as in 1979. These figures can be criticized : slowing down in investments, coal development, etc. could affect some LNG projects ; however, this will not change the importance of the growth of this sector.

\section{$L N G$ projects}

A list of the existing projects is given in Table 2. It can be noticed that projects under construction/firm are close to double the present capability. Japan and the USA are the most probable candidate for reception terminals of probable and possible projects.

\section{LNG carriers fleet}

Table 3 shows the importance of the existing fleet and of the orders placed. In addition there are a number of prospects for new orders which are likely to be firm during 1981, all these for large carriers, in the $125000 \mathrm{~m}^{3}$ plus category.

\section{Peak-shaving and satellite facilities}

We do not dispose of recent figures. However, as a reference, one can consider that figures supplied for the U.S. including operating and planned facilities gave : one liquefaction, five receiving terminals, 54 peak-shaving and 23 satellite facilities.

\section{Table 2 : Existing projects}

\section{OPERATING PROJECTS}

\begin{tabular}{|c|c|c|c|c|c|}
\hline \multirow[t]{2}{*}{ Project } & \multirow[t]{2}{*}{ Start } & \multirow[t]{2}{*}{ Contract } & \multirow{2}{*}{$\begin{array}{l}\text { Plateau Volume } \\
\text { (MMSCFD) }\end{array}$} & \multicolumn{2}{|c|}{ Terminals } \\
\hline & & & & Liquefaction & Reception \\
\hline $\begin{array}{l}\text { Algeria-UK } \\
\text { Algeria-France I } \\
\text { Algeria-France II } \\
\text { Algeria-Spain } \\
\text { Algeria-USA } \\
\text { Algeria-USA }\end{array}$ & $\begin{array}{l}1964 \\
1965 \\
1973 \\
1976 \\
1971 \\
1978\end{array}$ & $\begin{array}{l}15 \mathrm{yrs} \\
25 \mathrm{yrs} \\
25 \mathrm{yrs} \\
25 \mathrm{yrs} \\
27 \mathrm{yrs} \\
25 \mathrm{yrs}\end{array}$ & $\begin{array}{r}100 \\
100 \\
350 \\
450 \\
115 \\
1000\end{array}$ & $\begin{array}{l}\text { Arzew (Camel) } \\
\text { Arzew (Camel) } \\
\text { Skikda } \\
\text { Skikda } \\
\text { Skikda } \\
\text { Arzew } 1\end{array}$ & $\begin{array}{l}\text { Canvey Is. } \\
\text { Le Havre } \\
\text { Fos } \\
\text { Barcelona } \\
\text { Boston } \\
\text { Cove Pt. } \\
\text { Savannah }\end{array}$ \\
\hline $\begin{array}{l}\text { Abu Dhabi-Japan } \\
\text { Brunei-Japan }\end{array}$ & $\begin{array}{l}1977 \\
1973\end{array}$ & $\begin{array}{l}20 \text { yrs } \\
22 \text { yrs }\end{array}$ & $\begin{array}{l}400 \\
755\end{array}$ & $\begin{array}{l}\text { Das Is. } \\
\text { Lumut }\end{array}$ & $\begin{array}{l}\text { Sodegaura } \\
\left\{\begin{array}{l}\text { Yokohama } \\
\text { Sodegaura } \\
\text { Osaka }\end{array}\right.\end{array}$ \\
\hline $\begin{array}{l}\text { Indonesia-Japan } \\
\text { Indonesia-Japan }\end{array}$ & $\begin{array}{l}1977 \\
1978\end{array}$ & $\begin{array}{l}20 \text { yrs } \\
19 \text { yrs }\end{array}$ & $\begin{array}{l}410 \\
640\end{array}$ & $\begin{array}{l}\text { Badak } \\
\text { Arun }\end{array}$ & $\left\{\begin{array}{l}\text { Osaka } \\
\text { Kansai } \\
\text { Kyushu }\end{array}\right.$ \\
\hline $\begin{array}{l}\text { Libya-Italy } \\
\text { Libya-Spain } \\
\text { Alaska-Japan }\end{array}$ & $\begin{array}{l}1970 \\
1970 \\
1969\end{array}$ & $\begin{array}{l}20 \text { yrs } \\
15 \text { yrs } \\
15 \text { yrs }\end{array}$ & $\begin{array}{l}235 \\
110 \\
160\end{array}$ & $\begin{array}{l}\text { Marsa El Brega } \\
\text { Marsa El Brega } \\
\text { Kenai }\end{array}$ & $\begin{array}{l}\text { La Spezia } \\
\text { Barcelona } \\
\text { Tokyo }\end{array}$ \\
\hline
\end{tabular}


(Table 2, continued)

PROJECTS UNDER CONSTRUCTION/FIRM

$\begin{array}{ll}\text { Algeria-USA } & 1981 \\ \text { Algeria-France III } & 1981 \\ \text { Algeria-Belgium } & 1982 \\ \text { Nigeria-Germany } & 1984 / 5 \\ \text { Nigeria-France } & 1984 / 5 \\ \text { Nigeria-Italy } & 1984 / 5 \\ \text { Nigeria-Belgium } & 1984 / 5 \\ \text { Nigeria-Holland } & 1984 / 5 \\ \text { Nigeria-Spain } & 1984 / 5 \\ \text { Indonesia-USA } & 1983 \\ \text { Alaska-USA W. coast } & 1984 / 5 \\ \text { Malaysia-Japan } & 1983 \\ \text { W. Canada-E. coast N. America }\end{array}$

461

498

483

223

135

87

97

58

539

431

850

225
Arzew 2

Arzew 2

Arzew 2

Bonny

Bonny

Bonny

Bonny

Bonny

Bonny

Arun

Cook Inlet

Bintulu

Drake Pt.
Gulf Coast

St. Nazaire

Zeebrugge

California

California

Tokyo

PROBABLE PROJECTS

Malaysia-Japan

Australia-Japan

Indonesia-Japan

Indonesia-Japan

Canada-Japan

1986

1983

1985

Bintulu

Tokyo

Arun

Badak

800

425

410

400

POSSIBLE PROJECTS

Chile-Japan

Chile-USA

250

250

163-478

Trinidad-USA

Table 3 : LNG carriers fleet

\begin{tabular}{|lcc|}
\hline \multicolumn{3}{c|}{ EXISTING FLEET } \\
Size range & number & total capacity $\left(\mathrm{m}^{3}\right)$ \\
$0-5000 \mathrm{~m}^{3}$ & 8 & 22,554 \\
$25-50,000 \mathrm{~m}^{3}$ & 14 & 503,468 \\
$70-90,000 \mathrm{~m}^{3}$ & 11 & 848,662 \\
$120-133,000 \mathrm{~m}^{3}$ & 32 & $4,029,972$ \\
\multicolumn{3}{c}{ LNG CARRIERS ON ORDER } \\
$120,000 \mathrm{~m}^{3}+\quad 10$ & $1,284,600$ \\
\hline
\end{tabular}

\section{Risk analysis}

The intrinsic gas properties, the Cleveland accident, the growing importance of LNG in industrial countries' economies have played a large role in focusing the attention of public authorities, engineering companies and operators on safety problems. Efforts 
have been such that no major accident has been reported since the war, in spite of the size of the operations described in the previous chapters. As a more specific example, it should be borne in mind that the 90 or so existing peak-shaving plants in the U.S. have accumulated approximately 860 tank-years experience of safe operation. On the other hand, the number of voyages by LNG ships through 30th June, 1978 to European, Japanese and U.S. terminals has totalled 3578 without major accidents.

However, the growing dependence on LNG, particularly by the U.S. (several terminals should be built in the next few years) has brought renewed interest from public authorities in this matter and a number of studies have been promoted to better assess the risk associated with LNG operations.

As a matter of fact, regulatory bodies are reluctant to grant licensing approval for LNG operations, due to the limited data available on the consequences of a major LNG accident.

Among the various $R$ \& $D$ programmes to fill this gap, the most comprehensive is the one promoted by the Division of Environmental Control Technology in the U.S. which was started at the end of 1976 in collaboration with the U.S. Coast Guard and the American Gas Association. The Energy Research \& Development Administration (ERDA) has also provided an input.

This programme, which has to be completed within five years, has two major objectives :

- to develop and validate the analytical models necessary to describe, from a safety and environmental control viewpoint, the behaviour of LNG systems and the possible effects of LNG releases on the environment;

- to investigate and validate the methods to prevent and control the release of LNG.

To achieve these objectives, six technical aspects have been identified and the degree of financial support given is a fair measure of the perception of the need for more information. These aspects are presented in Table 4.

Table 4

\begin{tabular}{|l|r|}
\hline & $\begin{array}{c}\text { Financial support } \\
\text { (in million US \$) }\end{array}$ \\
\hline Vapour generation and dispersion & 3.5 \\
Fire and radiation hazards & 2.0 \\
Flame propagation & 3.5 \\
Release prevention and control & 3.0 \\
Instrumentation and technique development & 3.0 \\
Scale effect experiments & 35.0 \\
\hline TOTAL & 50.0 \\
\hline
\end{tabular}


Table 5 : Risk parameters and variables

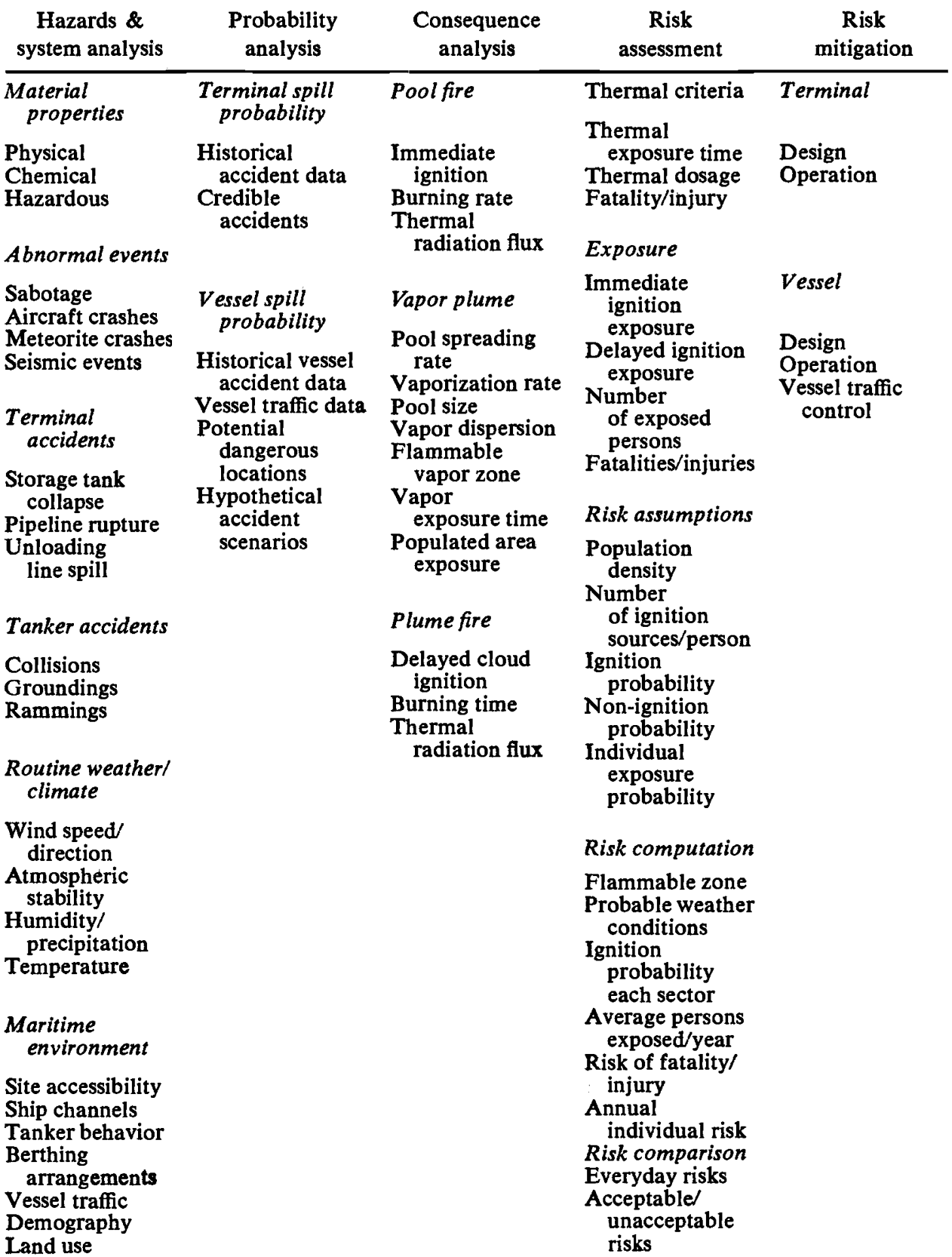


That $70 \%$ of the budget is devoted to the scale-effect experiments clearly shows where the crucial point of the question lies. Actually, this element is intended to provide the experimental data necessary to establish firmly whether the analytical models can predict the effects of large-scale events (LNG release, fire, etc.). Some ships can carry over $150000 \mathrm{~m}^{3}$ but research has only dealt with up to $10 \mathrm{~m}^{3} \mathrm{LNG}$. Various consequence-prediction models have been developed and tested against data from these small LNG spills. Are such models adequate for extrapolation to spills thousands of times larger?

In parallel, a number of other studies have been carried out, and in a study by Battelle-Geneva, over 300 publications on LNG risk-related aspects have been summarized under 18 different headings.

We are therefore facing a problem similar to that of nuclear plants, as stated before, and a quantitative risk analysis undergoes the same criticisms.

To appreciate the type of process adopted for these analyses, one can refer to the assessment of a liquefied natural gas terminal, presented in résumé at the TNO conference in Rotterdam in 1977.

A list of parameters and variables to be considered in the case of LNG is proposed by $P$. Martino in Table 5 .

As far as the ship incidents are concerned, these are more easily known and are approximately 1.5 per year.

A paper on the analysis of the LNG import terminal release-prevention system has been presented at the 1981 cryogenic engineering conference, San Diego, Cal., by E. G. Baker and P. J. Pelto of the Battelle Pacific Northwest Laboratory. Their

Table 6: Release scenarios for marine terminal and unloading operations

\begin{tabular}{|c|c|c|}
\hline & \multicolumn{2}{|c|}{ Release Scenarios } \\
\hline & 1 & 2 \\
\hline & $\begin{array}{l}\text { Rupture of loading } \\
\text { arm of components } \\
\text { during transfer }\end{array}$ & $\begin{array}{l}\text { Rupture of main } \\
\text { transfer line or } \\
\text { components during } \\
\text { transfer }\end{array}$ \\
\hline Expected number of events per year & $2 \times 10^{-3}$ & $4 \times 10^{-3}$ \\
\hline Release is not isolated & & \\
\hline Events per demand & $1 \times 10^{-2}$ & $3 \times 10^{-4}$ \\
\hline $\begin{array}{l}\text { Release occurs and is not isolated } \\
\text { Events per year }\end{array}$ & $2 \times 10^{-5}$ & $1 \times 10^{-6}$ \\
\hline \multicolumn{3}{|l|}{$\begin{array}{l}\text { Maximum release size } \\
\text { (equ. gallons of LNG) }\end{array}$} \\
\hline - 1 minute & 15000 & 500000 \\
\hline - 10 minutes & 130000 & 970000 \\
\hline
\end{tabular}


conclusions are derived from an extensive research work supported by the Environmental and Safety Engineering Division of the U.S. Department of Energy. Release Scenario Analysis has been performed through analytical methods including i) preliminary hazards analysis, ii) FMEA (failure modes and effects analysis) and iii) fault tree analysis.

Their conclusions for the release scenarios are summarized in tables 6 to 9 .

Table 7 : Failure information related to $L N G$ storage tanks

\begin{tabular}{|lr|}
\hline & $\begin{array}{c}\text { Frequency }{ }^{*} \\
\text { (per year) }\end{array}$ \\
\hline $\begin{array}{l}\text { Fire in liquid petroleum product tank or } \\
\text { other flammable liquid storage tank }\end{array}$ & $3 \times 10^{-4}$ \\
Fire/explosion at LPG storage tank & $3 \times 10^{-6}$ \\
Failure of a tank containing non-flammable materials & $3 \times 10^{-5}$ \\
Failure of LNG storage tanks & $1 \times 10^{-6}$ \\
Major spill from LNG storage tanks & $<3 \times 10^{-4}$ \\
Very large release from LNG storage tank & $3 \times 10^{-5}$ \\
\hline
\end{tabular}

* For this section, data from the following sources were used:

- S. Atallah: "Assessing and Managing Industrial Risk", Chemical Engineering, 1980;

- Safety and Reliability Director : Canvay - An Investigation of Potential Hazards from Operations in the Canvay Island/Thurrock Area, Her Majesty's Stationary Office, London, 1978.

Table 8 : Release scenarios for storage section

\begin{tabular}{|c|c|c|c|}
\hline & & Events/year & $\begin{array}{l}\text { Maximum possible release size } \\
\text { (Equivalent gallons of LNG) }\end{array}$ \\
\hline 3. & $\begin{array}{l}\text { Catastrophic failure of } \\
\text { a storage tank }\end{array}$ & $1 \times 10^{-5}$ & $23,000,000$ \\
\hline 4. & $\begin{array}{l}\text { a) Storage tank is } \\
\text { overfilled and } \\
\text { relief valves open }\end{array}$ & $2 \times 10^{-3}$ & $4,000 \mathrm{gpm}$ until filling is stopped (1) \\
\hline & $\begin{array}{l}\text { b) Filling is not stopped } \\
\text { and serious overflow } \\
\text { occurs }\end{array}$ & $1 \times 10^{-5}$ & $23,000,000(2)$ \\
\hline 5. & $\begin{array}{l}\text { a) Storage tank is over- } \\
\text { pressed during filling } \\
\text { and relief valves open }\end{array}$ & $5 \times 10^{-1}$ & $4,000 \mathrm{gpm}$ until filling is stopped (1) \\
\hline & $\begin{array}{l}\text { b) Storage tank is over- } \\
\text { pressured and relief } \\
\text { valves fail }\end{array}$ & $1 \times 10^{-6}(3)$ & $3,600,000(4)$ \\
\hline
\end{tabular}


(Table 8, continued)

\begin{tabular}{|c|c|c|c|c|c|}
\hline \multirow{4}{*}{\multicolumn{2}{|c|}{$\begin{array}{l}\text { 6. a) Storage tank is under- } \\
\text { pressured and vacuum } \\
\text { relief valves open } \\
\text { b) Storage tank is under- } \\
\text { pressured and vacuum } \\
\text { relief valves fail }\end{array}$}} & $2 \times 10^{-3}$ & \multicolumn{3}{|l|}{0} \\
\hline & & $1 \times 10^{-8}(5)$ & $3,600,000(4)$ & & \\
\hline & & \multirow[t]{2}{*}{ Events/year } & \multirow[t]{2}{*}{$\begin{array}{c}\text { Release } \\
\text { occurs and is } \\
\text { not isolated } \\
\text { Events/year }\end{array}$} & \multicolumn{2}{|c|}{$\begin{array}{l}\text { Maximum release size } \\
\text { (equivalent gallons } \\
\text { of LNG) }\end{array}$} \\
\hline & & & & 1 minute & 10 minutes \\
\hline 7. & $\begin{array}{l}\text { Rupture of storage tank } \\
\text { inlet line }\end{array}$ & $2 \times 10^{-6}$ & $4 \times 10^{-8}$ & 61,000 & 540,000 \\
\hline 8. & $\begin{array}{l}\text { Rupture of storage tank } \\
\text { outlet line }\end{array}$ & $3 \times 10^{-5}$ & $5 \times 10^{-7}$ & 5,000 & 41,000 \\
\hline 9. & $\begin{array}{l}\text { Rupture of secondary pump } \\
\text { or associated piping and } \\
\text { valves }\end{array}$ & $2 \times 10^{-3}$ & $3 \times 10^{-5}$ & 5,000 & 41,000 \\
\hline
\end{tabular}

Table 9 : Release scenario for vaporization section

\begin{tabular}{|c|c|c|c|}
\hline $\begin{array}{l}\text { Expected } \\
\text { number } \\
\text { of events }\end{array}$ & $\begin{array}{l}\text { Release is } \\
\text { not isolated } \\
\text { Events }\end{array}$ & $\begin{array}{l}\text { Release } \\
\text { occurs } \\
\text { and is not } \\
\text { isolated } \\
\text { Events }\end{array}$ & $\begin{array}{c}\text { Maximum release size } \\
\text { (Equivalent gallons } \\
\text { of } \mathrm{LNG} \text { ) }\end{array}$ \\
\hline per year & per demand & per year & 1 minute 10 minutes \\
\hline
\end{tabular}

Release scenarios

10. Vaporizer tube (sub. comb.) or plate (open rack) rupture $5 \times 10^{-1} 1 \times 10^{-1} 5 \times 10^{-2} \quad 1,700 \quad 9,100$

11. Rupture of vaporizer outlet line due to cold gas (vaporizer control failure) $8 \times 10^{-2} 1 \times 10^{-2} \quad 1 \times 10^{-3} \quad 2,000 \quad 11,000$

12. Rupture of vaporizer gas header or gas line to pipeline $1 \times 10^{-4} \quad 1 \times 10^{-2} \quad 1 \times 10^{-6} \quad 16,000 \quad 88,000$

Using the FMEA and fault trees developed to analyse the release scenarios, Battelle examined, on a preliminary basis, the effect of various design alternatives on the expected number of events and on the size of the release for some of the more critical scenarios (See Table 10). All of these alternatives are technically feasible and 
many have been used in at least one LNG facility. These systems would provide on the average a failure rate decrease by approximately a factor 10 . While these modifications still require technical and economic analysis, their benefit seems considerable for plants located near inhabited areas, but not worthwhile if adopted for remote plants.

Table 10 : Import terminal design alternatives

\begin{tabular}{|ll|}
\hline Emergency Shutdown System & Storage Tank \\
1. Redundant sensors & 1. Two cryogenic metal, independent, \\
2. Automatic activation & self-supporting containers \\
Main Transfer Line & 2. Pre-stressed concrete tanks \\
1. Double ply expansion joints & 3. Earthen or concrete berms \\
2. Double wall transfer line & 5. Redundant instrumentation \\
3. Two smaller transfer lines & 6. External primary sendout pumps \\
4. Offshore emergency shutdown &
\end{tabular}

\section{The position of industry}

The previous pages show how much research is conducted to assess the risks associated with LNG. However, two basic remarks must be made ;

- given the limited number of accidents occurred, no statistical basis for LNG risk assessment exists ;

- knowledge is still limited on basic topics, such as vapor cloud behaviour.

We therefore decided, in the framework of a study for the Geneva Association, to contact several companies operating in different LNG sectors to try to obtain the opinions of their specialists, who are acquainted with both the industrial situation and the scientific and technical progress in this area.

A questionnaire was prepared in this respect, the answers to which were to indicate to what extent a consensus exists and thus to enable us to classify the most critical situations and identify in which areas more knowledge and preventive measures are required. This questionnaire, prepared by Battelle and discussed with several companies involved in the LNG business before its mailing, was to be followed by a second one, more specific on the critical topics identified. The Geneva Association has had a positive experience with answers on other topics, and this study had been defined to follow a similar procedure. However, in this particular case, the answers to the questionnaire have been very limited.

Our questionnaire was addressed to over 40 companies, but only a few were returned, partially filled in and sometimes after insistent reminders. The results had therefore to be complemented by discussions with experts in various companies. 
The following conclusions can be reached.

Liquefaction of natural gas

(includes export and import terminals and peak-shaving facilities)

The single most critical factor for possible failures seems to be the instrumentation, followed, in decreasing order of importance, by human errors (carelessness and misinterpretation) and by welding defects. Risks associated to earthquake and storms apply only to specific geographical areas (for example, U.S. west coast).

The four causes mentioned could lead to 5/10 accidents each per year worldwide. Other causes would have a much lower impact (raw materials, internal rupture of parts, metallurgical defects, mechanical and electrical defects, design errors, breakage of rotating equipment, unskilled operators, lightning and floods, terrorist and vandal activities, air crashes, disasters of adjacent non-LNG-related facilites).

These accidents would however most often result in no leak or leak-and-safedispersal of the vapor cloud (over $90 \%$ of cases, in case of equipment failure and human errors, and approximately $50 \%$ in case of natural events), and leak and fire with losses under US $\$ 1000000$ (in 5-10\% of cases). The probability of fire or explosion with loss of lives would only occur in $1 \%$ of total cases.

This means 5-10 accidents per year, worldwide, 0.25 to 1 of which accompanied by minor physical losses and 0.05 to 0.1 of which causing loss of human lives.

Only in case of accidents due to hazards the probability of leak and safe dispersal of vapor cloud would be limited and loss of equipment or even of lives probable (15-20\%). It must be stressed that certain authors of questionnaires evaluate at nil the risk of losses in all these cases.

The most promising areas for reduction of accidents in LNG liquefaction units would be : more training of personnel (reduction of approximately $40 \%$ of relevant accidents), increased distance from inhabited areas to reduce impact of natural events $(30 \%)$ and more inspection $(30 \%)$.

\section{Transportation-transfer of LNG (all types included)}

Also in this case, instrumentation seems to be the single most critical area, and instrument failure is expected to be responsible for 5-10 accidents per year. All the other causes would bring less than five accidents per year. Safe dispersal of vapor cloud would occur in close to $90 \%$ of cases of equipment failure, limited loss of equipment in up to $40 \%$ of cases, and total loss of equipment and/or loss of lives in $2 \%$ of cases. Even lower losses would occur in case of human error $(0.6 \%$ probability of loss of lives). On the other hand, natural events and hazards would the most often result in some type of accident (50\% and $40 \%$ of cases respectively) up to a maximum of $25 \%$ of accidents implying loss of lives in case of natural events. Also in this case the most promising areas for decreasing the probability of accidents are considered to be more training, more inspection and duplication or triplication of controls. This could reduce by $30 \%$ the probability of the relevant accidents. Other 
measures suggested have been : better instrumentation, adoption of nuclear standards for certain parts, better choice of materials, remote siting of transfer units.

\section{Conclusions}

Clearly, the conclusions above reflect the official industry's opinion and, as such, can be suspected of partiality. We had, however, several discussions with individuals in industry and got the impression that, as engineers, conscious of the technical problems, having proposed solutions, their respective companies having invested an enormous amount of money for safety of their operations, the opinions they have expressed to us really reflect their personal perception of the potential risks. Actually, they identified areas for further progress in safety (instrumentation, for example) and research is going on in these specific fields at least allowing that the number of accidents induced will not increase in spite of the increased volume of the total LNG operations. They also admitted that increased distance of operations from inhabited areas would be beneficial (also if mainly to reduce the impact of natural events, whose probability of occurrence depends on the specific site), and this is also what industry is now doing, at least in the U.S. where the powerful public organisations have had the opportunity to take firm positions in this respect (cf. the case of Shell in California) and where legislation is stringent, requiring a detailed environmental impact assessment.

During our discussions with industry we could nevertheless confirm certain points related to the answers to our questionnaire and to detect some other reactions that we can summarize in the following points :

a) Human errors appear to be a most critical area and are expected to grow in the future. Also, it is a field where it is possible to intervene with acceptable operation costs increase, through more training, more inspection and more control. Especially, the interface man/machine (control panels, for example) can be improved.

b) Certain hazards, like air crashes, could originate catastrophy but their probability of occurrence is extremely low (in the order of $10^{-6}$ air crashes per year for the European countries, for example). This suggests, however, that location of operations should be far from inhabited areas, and this is not always the case in the importing countries.

c) Finally, it has appeared to us that the most critical step in the LNG operations chain is in the importing harbours manoeuvring, and docking. This is normal if one considers that these are often industrial areas with heavy activity, where natural conditions (atmospheric, weather, sea-storms, etc.) can play an important role, and therefore no human errors can be admitted. Furthermore, to our knowledge, LNG carriers are submitted to insurance coverage which does not take enough consideration of their hazardous cargo. In case of explosion in a port, the consequences for loss of property and lives would be far beyond the compensation allowed by the present forms of insurance. 